\title{
GENDER EQUALITY IN THE INSTITUTIONAL FRAMEWORK OF THE EU AND THE REPUBLIC OF SERBIA
}

\author{
UDC 342.722-055.1/.2(497.11:4-672EU)
}

\author{
Katarina Štrbac, Brankica Janković \\ Ministry of Defence of the Republic of Serbia, Belgrade, Republic of Serbia
}

\begin{abstract}
Promoting and achieving full gender equality is one of the key activities of the European Union and there is a strategic commitment to act strongly towards this goal. Gender equality is perceived, among others, as the issue of economic growth. Therefore, gender perspective has to be implemented through all EU activities. The Republic of Serbia, as a candidate for full EU membership, has fully accepted all goals that should be accomplished in accordance with European strategic documents. It has incorporated almost all EC directives concerning the equality of men and women into the legal system. First, the Republic of Serbia has developed the legal and institutional framework for the implementation of directives and strategic documents in the further process of negotiations for EU accession, and is continuously working on further improvement and completing of this system. The control mechanisms for observing the equality principle and prohibition of discrimination are established and functional, which primarily refers to the central state institution for protecting all citizens from all types of discrimination, including discrimination on grounds of sex-the Commissioner for Protection of Equality. The introductory part of this paper provides an overview of Strategic priorities of the European Union related to gender equality in five areas, and discusses their significance for the social development of the member states. The central part of the paper presents the institutional framework for the implementation and control of observance of the gender equality principle in the Republic of Serbia, including a summary outline for the implementation of gender equality.
\end{abstract}

Key words: gender equality, European Commission, Government Republic of Serbia

Received July $8^{\text {th }}, 2019 /$ Accepted July $22^{\text {nd }}, 2019$

Corresponding author: Katarina Štrbac, PhD, Advisor for gender equality, Ministry of Defence of the Republic of Serbia, 5 Bircaninova Street, 11000 Belgrade, Republic of Serbia; E-mail: katarina.strbac@mod.gov.rs 


\section{GENDER EQUALITY IN THE EUROPEAN COMMISSION}

Promoting gender equality is a core activity for the EU: equality between women and men is a fundamental EU value ${ }^{1}$, an EU objective ${ }^{2}$ and a driver for economic growth ${ }^{3}$. The Union shall aim to promote equality between men and women in all its activities ${ }^{4}$. The Commission's 2010-2015 Strategy for equality between women and men ${ }^{5}$ prioritised five key areas for action:

- equal economic independence for women and men;

- equal pay for work of equal value;

- equality in decision-making;

- dignity, integrity and ending gender-based violence; and

- promoting gender equality beyond the EU.

All five key areas identified in 2010 remain valid today. The action taken over the past five years to address gender inequalities needs more time to secure the necessary changes and support in the form of new measures in these areas. At the same time, recent socio-economic changes resulting from the economic crisis, the rapid spread of digital technology and immigration and integration have a significant impact on gender equality. Efforts are required of all actors if we are to achieve real equality between women and men in all spheres of life within the EU and elsewhere.

More and more Member States are addressing gender equality challenges through national strategies or action plans for equality between women and men. These vary in focus and ambition but they all cover policies on gender-based violence and gender equality in the labour market. Education and training, gender stereotypes and the reconciliation of work and family life are also covered extensively; decision-making is the least addressed area.

Without inquiring into other aspects of women's lives in the EU, such as the issues of economic equality and equal chances for occupying management positions, it is a fact that a significant number of women has experienced gender-based violence. Genderbased violence is still wide spread and can take many forms: one woman in three has experienced physical or sexual violence, $5 \%$ have been raped since the age of 15 , and $20 \%$ have experienced online harassment. ${ }^{6}$ Such violence happens everywhere - at home, at work, at school, in the street and online, regardless of social background. Gender-based violence and negative stereotypes in sport, for instance are widespread ${ }^{7}$. In addition, it is estimated that 500,000 women and girls in the EU are at risk of female genital mutilation

\footnotetext{
${ }^{1}$ Consolidated version of the Treaty on European Union, Article 2, Official Journal of the EU, C 115/13, 2008

${ }^{2}$ Consolidated version of the Treaty on European Union, Article 3, Official Journal of the EU, C115/13, 2008

${ }^{3}$ OECD (2012), Closing the gender gap: act now; https://www.oecd.org/gender/closingthegap.htm

${ }^{4}$ Consolidated version of the Treaty on the Functioning of the EU, Article 8, Official Journal of the EU, C326/1, 2012

5 The European Commission (2011). Strategy for equality between women and men 2010-2015 (COM(2010) 491.

https://publications.europa.eu/en/publication-detail/-/publication/c58de824-e42a-48ce-8d36-

a16f30ef701b/language-en

${ }^{6}$ EU Agency for Fundamental Rights (FRA); https://fra.europa.eu/en/about-fra

${ }^{7}$ European Commission (2016): Study on Gender-based violence in sport (Final Report), by L. Mergaert, C. Arnaut, T. Vertommen, M. Lang; https://ec.europa.eu/sport/sites/sport/files/gender-based-violence-sport-study2016_en.pdf
} 
$(\mathrm{FGM})^{8}$. Also, human trafficking is one of the most lucrative parts of organized crime in the EU member states and the greatest percentage of victims are women and girls $(68 \%$ women, $17 \%$ men, $12 \%$ girls and $3 \%$ boys $)^{9}$.

\section{EU Commissioner for Justice, Consumers and Gender Equality}

The Commissioner's responsibility within the EC gender equality framework includes:

- Fighting discrimination, promoting gender equality and pursuing negotiations on the proposed Anti-Discrimination Directive, which would ban discrimination in all areas where the EU has jurisdiction.

- Ensuring the swift adoption of the EU data protection reform and modernising and simplifying consumer rules for online and digital purchases.

- Concluding negotiations with the United States on a data protection agreement to protect the privacy of EU citizens wherever they live.

- Setting up an independent European Public Prosecutor's office by 2016 to protect the EU budget from fraud and reinforcing judicial cooperation on criminal matters.

- Concluding the EU's accession to the Convention for the Protection of Human Rights and Fundamental Freedoms of the Council of Europe

- Ensuring that all Commission proposals respect the European Charter of Fundamental Rights ${ }^{10}$.

Gender Equality and empowerment of women and girls are fundamental human rights. Both are vital for economic growth, prosperity and competitiveness. Gender equality is an essential precondition for equitable and inclusive sustainable development, which will not take place if half of the world's population is left behind. In spite of significant development in this area, the level of achievement of gender equality has been uneven across regions and within countries. Worldwide, girls and women keep bring systematically left behind and discriminated against, and persistent violations of their rights occur on a daily basis.

The European Union strongly supports gender equality and empowerment of women worldwide, working to remove the obstacles such as legislation, social norms and gender stereotypes, to ensure girls and women's participation and to increase their agency in social, economic, political and civil life. The crucial significance of gender equality in EU development policies is recognized in various policy documents. The "EU Strategic engagement for gender equality" highlights the promotion of gender equality and women's rights across the world as one of its five thematic priority areas. In the period 2007-2013, the EU committed an amount of EUR 1,258 million to activities targeted at improving gender equality and girls and women's empowerment. OECD data show that in 2013, 39\% of the EU Official Development Assistance (ODA) considered gender dimensions as either significant or principal.

\footnotetext{
8 European Parliament Resolution on ending female genital mutilation (FGM), 2012/2684(RSP); http://www.europarl.europa.eu/sides/getDoc.do?pubRef=-//EP//TEXT+TA+P7-TA-2012$0261+0+\mathrm{DOC}+\mathrm{XML}+\mathrm{V} 0 / / \mathrm{EN}$

${ }^{9}$ Eurostat (2013): EC Press Release, Bussels; http://europa.eu/rapid/press-release_MEMO-13-331_en.htm

10 European Commission (2019): Responsibilities of Commissioner for Justice, Consumers and Gender Equality; https://ec.europa.eu/commission/commissioners/2014-2019/jourova_en
} 
In October 2015, the EU adopted the Gender Equality and Women's Empowerment: Transforming Lives of Girls and Women through EU External Relations (2016-2020). This Gender Action Plan (GAP) focuses on taking action through four key areas:

- Ensuring girls' and women's physical and psychological integrity

- Promoting the economic and social rights / empowerment of girls and women

- Strengthening girls' and women's voice and participation

- Shifting the European Commission services' and the European External Action Services' institutional culture to more effectively deliver on EU commitments.

In the European Consensus on Development (2017), gender equality, promotion of women's rights, and the empowerment and protection of women and girls were highlighted as priorities across all areas of actions. ${ }^{11}$

Violence against women and girls is one of the most widespread, persistent and devastating human rights violations in our world today. In September 2017, the European Union (EU) and the United Nations (UN) embarked on a new, global, multi-year initiative focused on eliminating all forms of violence against women and girls (VAWG) - the Spotlight Initiative, which is to be implemented by the UN. With unprecedented funding of EUR 500 million, the EU has started a global movement to end all forms of violence against women and girls. ${ }^{12}$ The Initiative brings this issue into the spotlight and focuses on the efforts to achieve gender equality and women's empowerment, in line with the 2030 Agenda for Sustainable Development. The name of the Initiative suggests that violence often takes place in the dark, that it is often rendered invisible or denied, and that it cannot survive in the light. It also highlights the importance of targeted investments in women and girls to achieve sustainable development, making this renewed and unwavering commitment of the EU and the UN visible. It is a major obstacle to the fulfillment of women and girls' human rights and to the achievement of the 2030 Agenda for Sustainable Development. It occurs worldwide, cutting across all generations, nationalities, communities and spheres of our societies, irrespective of age, ethnicity, disability or other background. The Spotlight Initiative will deploy targeted, large-scale investments in Asia, Africa, Latin America, the Pacific and the Caribbean, aimed at achieving significant improvements in the lives of women and girls ${ }^{13}$.

The Gender Action Plan (GAP II) has the overarching objective of providing tools for supporting the progress of the EU and its 28 Member States on the attainment of the Agenda 2030 goals as well as the goals set out by the Convention on the Elimination of all forms of Discrimination Against Women (CEDAW), the Beijing Platform for Action, and the Cairo Programme of Action. Besides setting up and adopting a common process, the second GAP will reinforce the EU coordination and coherence regarding the realization and integration of gender equality policies in its external relations, and development cooperation activities. As a contribution to the 2030 Agenda, the EU and its Member States will translate this gender equality policy approach into concrete actions to empower women and girls, including tackling discrimination and violence against them. This includes three thematic priorities:

\footnotetext{
${ }^{11}$ EC International Cooperation and Development (2017): New European Consensus on Development - 'Our world, our dignity, our future, 8 June 2017, available at https://ec.europa.eu/europeaid/policies/europeandevelopment-policy/european-consensus-development_en

${ }^{12}$ EC International Cooperation and Development (2019): Gender equality; https://ec.europa.eu/europeaid/ sectors/human-rights-and-governance/gender_en

${ }^{13}$ EC International Cooperation and Development (2019): Spotlight Initiative; https://ec.europa.eu/europeaid/ sectors/human-rights-and-democratic-governance/gender-equality/spotlight-initiative_en
} 
- Physical and psychological integrity of women and girls

- Socio-economic rights/empowerment of women and girls

- Voice and participation for women and girls.

An overarching priority is the institutional cultural shift which aims at integrating gender equality in the "way of working" of all EU actors in external relations and development ${ }^{14}$.

The EU supports partner countries around the world in their efforts to secure lasting peace, promote their political stability or rebuild societies and infrastructures after crisis situations. The EU's priorities are to promote good governance, establish the rule of law, fight against crime and strengthen law enforcement. Wars and armed conflicts have devastating human and societal impacts, such as wide-spread violence, the tragedy of refugee camps, accelerated spread of HIV, and the destruction of lives, livelihoods, state institutions and infrastructure. Such calamities can cripple a country for generations. The EU supports initiatives aimed at eradicating some of the leading causes of conflict, safeguarding stability and reestablishing peace after a crisis. Alleviating poverty, tackling disease and promoting good governance help shape societies where all are given a chance to thrive. They also address a number of potential causes of unrest.

EU development work uses non-military means to support the peaceful prevention or resolution of armed conflict through activities such as negotiation, demobilisation and demilitarisation. It also supports:

- good policing;

- the rule of law (e.g. availability of judges and lawyers);

- civil administration (establishing a group of experts);

- civil protection (experts and emergency teams that can be mobilised at very short notice).

Conflict prevention is supported and reinforced by cooperation and association agreements, cooperation on justice and home affairs, development policy, humanitarian assistance, social and environmental programmes, and trade policy. ${ }^{15}$

\section{WOMEN, PEACE AND SECURITY IN THE REPUBLIC OF SERBIA DURING THE EUROPEAN UNION NEGOTIATIONS}

The Republic of Serbia is dedicated to the implementation of the Resolution 1325 and related UN Resolutions dealing with women, peace and security. Serbia is open to reviewing and exchanging positive experiences in practice, both in the Western Balkan region and in Europe and the world, especially the good practices and experiences it has had the opportunity to exchange during the collaboration with the Kingdom of Spain, Kingdom of Norway, Kingdom of Sweden, Kingdom of Netherlands, Federal Republic of Germany, United States of America, Israel and other countries, as well as the specialized bodies of the United Nations, such as the UN entity UN Women, the UNDP, within the Common Security and Defence Policy of the European Union (CSDP), the NATO/EuroAtlantic Partnership Council, the EAPC, but also through cooperation with certain international organizations such as the OSCE or the DCAF, etc.

\footnotetext{
${ }^{14}$ EC International Cooperation and Development (2019): Gender equality/Political commitment; https://ec.europa. eu/europeaid/sectors/human-rights-and-democratic-governance/gender-equality/political-commitment_en

${ }^{15}$ EC International Cooperation and Development (2019): Gender equality/Political commitment; https://ec.europa. eu/europeaid/sectors/human-rights-and-governance/peace-and-security_en
} 
Therefore, the Republic of Serbia is actively contributing to the total effort of international organizations, states and the civilian society organizations with the goal to improve the position of women, which is of utmost importance for respecting the right to equality and equal participation and representation of women and men in all spheres of social life, including the reformatory steps taken by the Republic of Serbia in the period between 2010 and 2016 for the purpose of gender equality integration into the security sector. These efforts led not only to changes at the institutional level, by establishing new gender equality bodies and mechanisms, but also to changes in legislation, strategies and plans. Not less important is the success achieved in raising awareness on gender issues of members of all the security sector institutions, primarily through education and training, but also through media promotion.

The results achieved in the previous five-year period of implementation of the National Action Plan for implementation of the UN SC Resolution 1325 on Women, Peace and Security in the Republic of Serbia (2010-2015) (hereinafter: the NAP) are visible today in almost all aspects of daily work and life of the security sector members. A significant progress had been made in achieving the NAP goals, especially in institutional development, increase of representation of women in the security sector and in the decision-making, increase of participation in the international cooperation activities and multinational operations, improvement of normative presuppositions for protection of women, media reporting on implementation of the NAP activities, as well as establishing cooperation of the state administration bodies, civil society organizations, Western Balkan countries and international organizations in the implementation of the UN SC Resolution 1325.

In this context, the development and implementation of this document have produced exceptionally positive effects in the state administration bodies where women are employed in operational units such as: the Ministry of Defence and the Serbian Armed Forces, the Ministry of Internal Affairs, the Customs Administration of the Ministry of Finance, the Directorate for Enforcement of Criminal Sanctions of the Ministry of Justice, and the Security Information Agency regarding the integration of gender equality into the reform process.

Given the fact that both the first and the second NAP for implementation of this Resolution include the "measurability" of effects of the activities contained in the Plan, it was determined by means of indicators that the representation of women in the security sector of the Republic of Serbia increased in the period between 2010 and 2015 for $4.13 \%$ (from $27.40 \%$ in 2010 to $31.53 \%$ in 2015 ); in the same period, the representation of women in decision-making (command/management) in the security system increased for $5.21 \%$ (from $14.47 \%$ in 2010 to $19.68 \%$ in 2015). Also, the total representation of women from the Ministry of Defence and the Serbian Armed Forces in multinational operations in 2015 was $10.06 \%$, while in the same period the representation of women from the Ministry of Internal Affairs in civilian missions was $5 \%^{16}$. There has been a significant increase of participation of women from the security system in international cooperation activities, and women were more often occupying the role of delegation

\footnotetext{
${ }^{16}$ Zaključak Vlade i Izveštaj PS za sprovodjenje NAP-a za primenu Rezolucije 1325 SB UN u R Srbiji u 2015 god.i, (Conclusion of the RS Government and Report of the Political Council on the implementation of the NAP for the implementation of the UNSC Resolution 1325 in the Republic of Serbia in 2015), available at http://www.mod.gov.rs/multimedia/file/staticki_sadrzaj/dokumenta/akcioni_planovi/2017/Zakljucak\%20Vlade $\% 20 \mathrm{i} \% 20$ Izvestaj\%20PS $\% 20 \mathrm{o} \% 20$ sprovodjenju $\% 20$ NAP $\% 20 \mathrm{za} \% 20$ primenu\%20R_\%201325\%20SB\%20UN $\% 20 u \% 20$ R_\%20Srbiji\%20u\%202015_\%20godini.pdf
} 
leaders during official visits abroad than in previous years. All forms of education in the military and the police are open to female participants. In 2016, in the $136^{\text {th }}$ class of cadets of the Military Academy, the three best cadets were female cadets from the Defence Logistics study programme, Finance module ${ }^{17}$.

The Republic of Serbia was positively evaluated during external evaluations for implementation of the UN SC Resolution 1325 Action Plans. The evaluations were performed by the OSCE Mission in cooperation with the Institute for Inclusive Security from Washington (USA), "One Earth Future" foundation, and Belgrade Centre for Security Policy. It is important to point out that the implementers of the evaluation pointed out in their report, based on the comparative analysis with other evaluated Plans, that "although the National Action Plan is not the best one, the Republic of Serbia is high up on the list of the plans analyzed, which is a confirmation of the results achieved by the institutions formed to implement the National Action Plan in the five-year period." The conclusions made based on the results of the internal and external evaluation served as the basis for development of the new mid-term Action Plan ${ }^{18}$.

By the Decision of the Government of the Republic of Serbia dated 25 December 2015, a Working Group for development of the National Action Plan for implementation of the UN SC Resolution 1325-Women, Peace and Security in the Republic of Serbia (2016-2020) (hereinafter the Working Group) was established, and its composition and tasks were defined. In relation to the previous Plan, the novelty was that the Group was composed of 31 persons from the state administration bodies, but it also included representatives from the local self-governments, civilian society organizations and academic community, who were equal participants in the development of the new Plan. During its first session (held in Belgrade on 11 January 2016), the Group adopted the Concept and the dynamic plan for the development of the National Action Plan and developed the Draft of the new Plan, which was presented in April 2016.

According to the pre-determined methodology, the Plan was developed within two workshops held with the support of the Standing Conference of Towns and Municipalities of Serbia and two workshops held with the support of the OSCE Mission in Serbia. The results of the workshops were considered at the Working Group sessions, implemented with the professional and administrative and technical support of the Ministry of Defence, and based on the public consultations and alignment of opinions with the representatives of all actors included in the Plan development and implementation. Before the adoption of the Plan, the Political Council of the Government adopted and delivered to the Working Group the Guidelines for Development of the National Action Plan for Implementation of the UN Security Council Resolution 1325 - Women, Peace and Security in the Republic of Serbia (2016-2020) in December 2015. During the development of the Draft Action Plan, in the period between 18 and 26 February 2016 as well as between 26 April and 10 June 2016, with the support of the Office for Cooperation with Civil Society, the Working Group organized electronic consultations with the civil society organizations on the form and content of the Plan. The Plan was made available to the public at the Office for Cooperation

\footnotetext{
${ }^{17}$ Blic (2015). Najbolje u klasi: Tri devojke prve u rangu na Vojnoj akademiji, published 04.09.2015, available at https://www.blic.rs/vesti/drustvo/najbolje-u-klasi-tri-devojke-prve-u-rangu-na-vojnoj-akademiji/2s9h2xq, (accessed 10.07.2019).

${ }^{18}$ National Action Plan for the Implementation of UN Security Council Resolution 1325 - Women, Peace and Security in the Republic of Serbia (2017-2020), https://www.peacewomen.org/sites/default/files/Serbia_ NAP.pdf
} 
with Civil Society website and the Ministry of Defence website, and the public could provide comments and suggestions via an online form.

As one of the results of the public consultation process, it was suggested that women should take greater part in peacekeeping missions and peace processes, and that rehabilitation and post-conflict recovery programmes should be made equally accessible to men and women in local communities in order to reduce the risk of rise of violence against women and children within families ${ }^{19}$.

The proposal of the National Action Plan (2017-2020) was disseminated by the Ministry of Defence to the state administration bodies of the Republic of Serbia on 12 September 2016. After the extensive process of harmonization on financial aspects of its implementation, it was delivered to the Government of the Republic of Serbia for adoption. The NAP (2017-2020) was adopted on 19 May 2017 by the Decision of the Government of the Republic of Serbia ${ }^{20}$.

By consistent adherence to the NAP (2017-2020), the Republic of Serbia respects the provisions of the Council of Europe Convention on Preventing and Combating Violence against Women and Domestic Violence (also known as the Istanbul Convention). This first comprehensive and legally binding agreement for the whole of Europe defines the notions such as: violence against women, domestic violence, gender-based violence against women, and it establishes the obligation of the signatory states to systematically combat gender-based violence. The Ministry of Defence is actively implementing the activities defined in the National Action Plan for implementation of the UN Security Council Resolution - Women, Peace and Security in the Republic of Serbia (the previous NAP for the period 2010-2015, as well as the current one for the period 2017-2020).

The total number of persons from the Ministry of Defence (MoD) and the Serbian Armed Forces (SAF) participating in multinational operations (MnOp) in the previous years did not increase significantly, but the percentage of women did increase in the contingents in 2018 in comparison to 2017. Namely, in 2017, the total of 656 persons took part in MnOp, out of whom 579 were men $(88.3 \%$ ), while $\mathbf{7 7}$ participants of the mission were women (11.7\%). In 2018, the number of females increased to $14.1 \%$. Out of the total of 559 persons taking part in the $\mathrm{MnOp}, 480$ were men (85.9\%), while 79 were women $(\mathbf{1 4 . 1 \%})^{\mathbf{2 1}}$.

Prior to deployment to missions, all mission participants (units, teams and individuals) are obliged to participate in trainings on prevention of sexual violence in conflicts. During the training, the disciplinary and criminal aspect of any form of sexual abuse or violence is pointed out both in relation to members of our national contingent and in relation to local population.

\section{The Coordination Body for Gender Equality}

The Coordination Body for Gender Equality was founded on $30^{\text {th }}$ October 2014 by the Government of the Republic of Serbia, headed by the Deputy Prime Minister, prof. Zorana Mihajlović PhD. The Coordination Body will consider all issues and coordinate

\footnotetext{
${ }^{19}$ Ibid.

${ }^{20}$ Ibid.

21 Evaluacija NAP za rodnu ravnopravnost 2016-2018, Finalni izveštaj evaluacije Akcionog plana za sprovođenje Nacionalne strategije za rodnu ravnopravnost Republike Srbije (Upitnik o realizaciji aktivnosti predvidjenih akcionim planom u periodu 2016-2018), Koordinaciono telo za rodnu ravnopravnost, Vlada Republike Srbije, https://www.secons.net/files/publications/99-publication.pdf
} 
the work of the State administration body in relation to gender equality in Serbia. The establishment of the Gender Equality Coordination Body is important for the process of European integration and the promotion of gender equality in Serbia. ${ }^{22}$

The Coordination Body is the national coordination mechanism for gender equality issues. It is mandated to coordinate the work of state administration bodies and other institutions for the purpose of improving gender equality and position of women and men in Serbia. The tasks of the Coordination Body are to initiate and monitor the implementation of strategic documents, laws and other regulations in the field of gender equality, provide expert opinions and manage the work of state bodies in tasks which exert a direct or indirect influence on gender equality and coordinate state administration bodies in the field of gender equality. ${ }^{23}$

\section{The Sector for Anti-discrimination Policy and Improvement of Gender Equality of the Ministry of Labour, Employment, Veteran and Social Affairs}

The Sector for Anti-discrimination Policy and Promotion of Gender Equality performs tasks relating to preparation and analysis of information and other analytical materials for the purpose of promoting the anti-discrimination policy and gender equality. Its jurisdiction includes development of laws and other regulations in the field of anti-discrimination and improvement of gender equality, as well as providing opinions and proposing measures for implementation of these regulations, development of analyses, reports and information on the status and application of regulations in this area, monitoring of developments in the EU acquis for this field, monitoring and preparation of reports on application of international conventions, monitoring the implementation of the recommendations of the UN Committee on the Elimination of Discrimination against Women (CEDAW) and performing tasks relating to international cooperation and activities in connection to access to international donor funds. $^{24}$

\section{The Protector of Citizens (Ombudsman) of Serbia}

The Ombudsman protects and promotes the rights of citizens through the control of legality of bodies and organizations' with public authority. The Ombudsman covers the gender equality issue as one of the questions within his scope of work, while one of the four Ombudsman deputies is primarily in charge of children's rights and gender equality (Pajvančic, Petrušić, 2014: 37). In 2018, the Ombudsman reviewed almost 100 cases in the area of gender equality and issued 144 recommendations to the administration bodies. During the control procedure in 30 cases of domestic violence, some of which ended in femicide, he established that there were irregularities in the work of state bodies and gave relevant recommendations to the authorities in charge of protection of women from violence. ${ }^{25}$

\footnotetext{
${ }^{22}$ Ministry of Construction, Transport and Infrastructure (2019): Coordination Body for Gender Equality; https://www.mgsi.gov.rs/en/coordination-body-gender-equality;

${ }^{23}$ Vlada Republike Srbije: Koordinacioniono telo za rodnu ravnopravnost (Government of the RS, Coordination Body for Gender Equality); https://www.rodnaravnopravnost.gov.rs/sr/o-nama/ko-smo-mi

${ }^{24}$ Ministarstvo za rad, zapošljavanje, boračka o socijalna pitanja (2019) Sektor za antidiskriminacionu politiku i unapređenje rodne radnopravnosti (Ministry of Labour, Employment, Veteran and Social Affairs, Sector for antidiscrimination policy and promoting gender equality); https://www.minrzs.gov.rs/sr/struktura/sektori/sektorza-antidiskriminacionu-politiku-i-unapredjenje-rodne-ravnopravnosti

${ }^{25}$ Danas , Beta (2019): Ombudsman: Žene u Srbiji ne mogu da slave 8. mart u duhu ostvarene ravnopravnosti (Ombudsman: Women in Serbia cannot celebrate Women's Day ( $8^{\text {th }}$ March) in the spirit of accomplished equality);
} 


\section{The Commissioner for Protection of Equality}

The Commissioner for Protection of Equality is an independent, autonomous and specialized state authority established on the basis of the 2009 Act on Prohibition of Discrimination. The task of this state authority is to prevent all forms, types and cases of discrimination, to protect the equality of natural persons and legal entities in all spheres of social relations, to oversee the enforcement of antidiscrimination regulations, and to improve the implementation and protection of equality.

The Commissioner for Protection of Equality is competent to carry out the procedure based on complaints in cases of discrimination against persons or groups of persons connected by the same personal characteristic. The Commissioner is competent to receive and consider complaints on discrimination, to issue opinions and recommendations in concrete discrimination cases, and to stipulate measures defined by the Law. In addition, the Commissioner is obliged to inform the complainant about his or her rights and possibilities to initiate a court procedure or another protection measure, including the reconciliation procedure. The Commissioner is also authorized to file complaints for protection from discrimination, with approval of the discriminated person. The Commissioner is also competent to file offence reports against discrimination acts prohibited by the antidiscrimination regulations.

The Commissioner is authorized to warn the public about the most common, typical and severe cases of discrimination, to monitor the enforcement of laws and other regulations, to initiate adoption or amendments to regulations with the aim of making them more enforceable and improving protection from discrimination, and to recommend measures to public authorities and other parties concerned for achieving equality. The Commissioner's competences also include monitoring the situation related to protection of equality and submitting the Commissioner's Annual report on this matter to the National Parliament. In her work, the Commissioner has the obligation to establish and maintain collaboration with authorities competent for safeguarding equality and human rights protection on the territories of the Autonomous Province and local self-governments. ${ }^{26}$

\section{CONCLUSION}

In the Republic of Serbia, the issue of gender equality came into focus with the development of the first NAP in 2010 and, in the years that followed, a series of positive steps for improvement of position of women has been made. At the same time, during the preparation for opening negotiations with the European Union and at the beginning of negotiation process the determination to work in the fields concerning gender equality was confirmed, especially in Chapter 23 - Judiciary and fundamental rights, Chapter 24 Justice, freedom and security, and Chapter 31 - Foreign, security and defence policy. If we consider the European Union report on this issue, it may be concluded that a lot has been done in the Republic of Serbia on the issue of gender equality, perhaps even more than in some of the EU member states.

published 7 March 2019; https://www.danas.rs/drustvo/ombudsman-zene-u-srbiji-ne-mogu-da-slave-8-mart-uduhu-ostvarene-ravnopravnosti/(accessed 28.06.2019.)

${ }^{26}$ The Commissioner for Protection of Equality (2016); Competences of the Commissioner for Protection of Equality; http://ravnopravnost.gov.rs/en/background-information 
In the first years after the adoption of the NAP in Serbia, the focus was on establishing the gender equality mechanisms, but also on providing better information to the public on this very important issue for human rights in general. The normative legal framework should be complete after adoption of the gender equality law, with all the previously adopted regulations concerning prevention of abuse of women at workplace, prevention of violence against women, economic equality of women, economic empowerment of women, etc. The education process, particularly at the undergraduate, graduate and postgraduate levels of study, has created a generation of young educated people with gender awareness. They need to continue raising awareness and building gender equality in Serbia. In the NAP 2017-2020, the importance of gender awareness and empowerment of women has shifted to local communities where improvement of position of women is also expected. The third NAP would require for the mechanisms established in the previous two NAPs to become fully functional. The weaknesses which were observed in the previous period should be eliminated, especially regarding the lack of understanding of the society's obligation to adopt all the positive regulations and norms of behavior.

\section{REFERENCES}

Consolidated version of the Treaty on European Union, Article 2, Official Journal of the European Union, C $115 / 13,2008$

Consolidated version of the Treaty on the functioning of the European Union, Article 8, Official Journal of the European Union, C 326/1, 2012

European Commission (2011). Strategy for equality between women and men 2010-2015 (COM(2010) 491), adopted in September 2010; Luxembourg Publication Office EU; available at https://publications. europa.eu/en/publication-detail/-/publication/c58de824-e42a-48ce-8d36-a16f30ef701b/language-en

EC (2016): Study on Gender-based violence in sport (Final Report) by L. Mergaert, C. Arnaut, T. Vertommen, and M. Lang; European Commission, Brussels; https://ec.europa.eu/sport/sites/sport/files/gender-basedviolence-sport-study-2016_en.pdf

EU Agency for Fundamental Rights (FRA); https://fra.europa.eu/en/about-fra

European Parliament Resolution on ending female genital mutilation (FGM), 2012/2684(RSP), http://www.europarl.europa.eu/sides/getDoc.do?pubRef=-//EP//TEXT+TA+P7-TA-2012$0261+0+\mathrm{DOC}+\mathrm{XML}+\mathrm{V} 0 / / \mathrm{EN}$

Eurostat (2013): EC Press Release Database, Bussels, 15 April 2013, http://europa.eu/rapid/press-release MEMO-13-331_en.htm

European Commission (2019): Responsibilities of Commissioner for Justice, Consumers and Gender Equality; https://ec.europa.eu/commission/commissioners/2014-2019/jourova_en

EC International Cooperation and Development (2019): Gender Equality https://ec.europa.eu/europeaid/ sectors/human-rights-and-governance/gender_en

EC International Cooperation and Development (2019): Gender Equality/Political Commitment; https://ec.europa.eu/europeaid/sectors/human-rights-and-democratic-governance/gender-equality/politicalcommitment_en

EC International Cooperation and Development (2019): Spotlight Initiative; https://ec.europa.eu/europeaid/ sectors/human-rights-and-democratic-governance/gender-equality/spotlight-initiative_en

EC International Cooperation and Development (2017): New European Consensus on Development, 8 June 2017, available at https://ec.europa.eu/europeaid/policies/european-development-policy/europeanconsensus-development_en

OECD (2012). Closing the Gender Gap: Act now, OECD Publication, 7 December 2012, available at https://www.oecd.org/gender/closingthegap.htm 


\section{SERBIAN SOURCES}

Blic (2015). Najbolje u klasi: Tri devojke prve u rangu na Vojnoj akademiji (Three girls best in their class), published 04.09.2015, available at https://www.blic.rs/vesti/drustvo/najbolje-u-klasi-tri-devojke-prve-urangu-na-vojnoj-akademiji/2s9h2xq, (accessed 10.07.2019).

Commissioner for Protection of Equality (2016): Competences of the Commissioner for Protection of Equality; http://ravnopravnost.gov.rs/en/background-information

Danas , Beta (2019): Ombudsman: Žene u Srbiji ne mogu da slave 8. mart u duhu ostvarene ravnopravnosti (Ombudsman: Women in Serbia cannot celebrate Women's Day in the spirit of attained equality); published 7 March 2019; https://www.danas.rs/drustvo/ombudsman-zene-u-srbiji-ne-mogu-da-slave-8mart-u-duhu-ostvarene-ravnopravnosti/ (accessed 28.06.2019.)

Evaluacija NAP za rodnu ravnopravnost 2016-2018, Finalni izveštaj evaluacije Akcionog plana za sprovođenje Nacionalne strategije za rodnu ravnopravnost Republike Srbije (Final Evaluation Report on the NAP for the implementation of the National Strategy for gender equality of R. Serbia), Koordinaciono telo za rodnu ravnopravnost, Vlada Republike Srbije, available at https://www.secons.net/files/publications/99-publication.pdf

Ministry of Construction, Transport and Infrastructure (2019): Coordination Body for Gender Equality; https://www.mgsi.gov.rs/en/coordination-body-gender-equality;

Ministarstvo za rad, zapošljavanje, boračka i socijalna pitanja (2019) Sektor za antidiskriminacionu politiku i unapređenje rodne radnopravnosti (Ministry of Labour, Employment, Veteran and Social Affairs, Sector for antidiscrimination policy and promoting gender equality); https://www.minrzs.gov.rs/sr/struktura/ sektori/sektor-za-antidiskriminacionu-politiku-i-unapredjenje-rodne-ravnopravnosti

National Action Plan for the Implementation of UN Security Council Resolution 1325 - Women, Peace and Security in the Republic of Serbia (2017-2020), https://www.peacewomen.org/sites/default/files/ Serbia_NAP.pdf

Пајванчић, М., Петрушић Н. (2014). Значај институционалних механизама за остваривање родне равноправности (The Importance of Institutional Mechanisms for Exercising Gender Equality), Zbornik radova Pravnog fakulteta u Nišu, br. 67. 2014 )pp 25-44 ); https://scindeks-clanci.ceon.rs/data/pdf/03508501/2014/0350-85011467025P.pdf

Vlada Republike Srbije: Koordinacioniono telo za rodnu ravnopravnost (Government of Republic of Serbia, Coordination Body for Gender Equality); https://www.rodnaravnopravnost.gov.rs/sr/o-nama/ko-smo-mi

Zaključak Vlade i Izveštaj PS za srovodjenje NAP-a za primenu Rezolucije 1325 SB UN u R Srbiji u 2015 god. (Conclusion of the RS Government and Report of the Political Council on the implementation of the NAP for the implementation of the UNSC Resolution 1325 in R.Serbia in 2015), http://www.mod.gov.rs/ multimedia/file/staticki_sadrzaj/dokumenta/akcioni_planovi/2017/Zakljucak\%20Vlade\%20i\%20Izvestaj\% 20PS\%20o\%20sprovodjenju\%20NAP\%20za\%20primenu\%20R_\%201325\%20SB\%20UN\%20u\%20R_\%2 0Srbiji\%20u\%202015_\%20godini.pdf

\section{RODNA RAVNOPRAVNOST U INSTITUCIONALNOM OKVIRU EU I REPUBLIKE SRBIJE}

Promovisanje i pun doprinos rodne ravnopravnosti je jedna od ključnih aktivnosti Evropske unije, kao i njeno strateško opredeljenje na dostizanju tog cilja. Rodna ravnopravnost je viđena, između ostalog, kao pitanje ekonomskog rasta i kao takva, rodna perspektiva je implementirana u sve aktivnosti Evropske unije. Republika Srbija, kao zemlja kadidat za članstvo u Evropskoj uniji, usvojila je sve ciljeve $u$ vezi sa rodnom ravnopravnošć koji treba da budu ispunjeni u skladu sa Evropskim strategijskim dokumentima, osim toga, u svim direktivama Evropske komisije jednakost između muškaraca i žena je inkorporirana u pravne sisteme zemlja članica. Kao prvo, Republika Srbija je obezbedila pravni $i$ institucionalni okvir za implementaciju direktiva $i$ strategija $u$ procesu pregovora za članstvo $u$ Evropskoj uniji, kao i kontinuiran rad na jačanju rodne ravnopravnosti. Kontrolni mehanizmi za poštovanje principa jednakosti, npr. sprečavanje diskriminacije, su formirani i funkcionišu, pre svega, državna institucija za zaštitu stanovništva od svih oblika diskriminacije, uključujući rodnu diskriminaciju - Poverenik za zaštitu ravnopravnosti. Autori u prvom delu naglašavaju značaj za socijalni razvoj država članica, u drugom delu rad se nastavlja upoznavanjem sa institucionalnim okvirom za implementaciju $i$ kontrolu poštovanja rodne ravnopravnosti u Republici Srbiji.

Ključne reči: rodna ravnopravnost, Evropska komisija, Vlada Republike Srbije 